\title{
ガスタービン用複合材料の研究開発の現状
}

\author{
大浜 信一

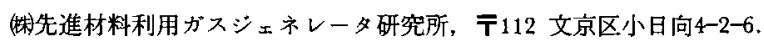

\section{Research and Development of Advanced Composite Materials for Gas Turbine Applications}

\author{
Shinichi Ohama \\ Research Institute of Advanced Material Gas-Generator, 4-2-6 Kohinata Bunkyo-ku, Tokyo 112.
}

Received February 1, 1996

\section{SYNOPSIS}

Composite materials offer many advantages when compared to an unreinforced matrix. The major advantage appears to be the ability to tailor mechanical and physical properties to meet specific needs.

Research and development of composite materials for gas turbine applications are being carried out by Research Institute of Advanced Material Gas-Generator. This paper introduces the outline of this project and presents outcome from initial three years of the program mainly manufacturing process deveropment of the gas turbine components of the composites.

\section{KEY WORDS}

Composite Material, PMC, MMC, CMC, Gas Turbine

\section{1 緒 言}

産業用、舶用及び航空用のガスタービンは, 近 来その技術的な進步とともに需要も急速に增大し ているが，将来のガスタービンには省資源性，環 境適合性を飛唯的に向上させることが強く要求さ れる超勢にある。このためにガスタービンの低燃 費化，小型・軽量化を図ることが不可久攵である. これらを実現するためには，ガスタービンの中枢 であるガスジェネレータの高温・高圧化が必須で あるが,この要求に応える材料として, 高強度・ 高弾性率でしかも耐熱性のある織維によって低密 度のマトリックスを強化した䄉維強化複合材料は ガスタービン用材料として理想的な材料といえよ う.本稿では, 椱合材料を主体とした先進材料の
ガスタービンヘの適用の研究開発の現状について ふれてみたい。

\section{2 ガスタービン用材料の動向}

典型的な航空用ガスタービンエンジンの断面図 をFig. 11に示す。本図において高圧压䑿機と 高压タービンは同軸で，またファン・低压压縮機 と低生タービンはをの内側の軸で連結され回転し ている、ガスタービンとしては, 前者の高圧压縮 機, 燃狫器, 高代タービンが基本的な構成であっ て、これらをガスタービンのコアまたはガスジェ ネレータと呼んでいる。陸用および舶用に使われ るガスタービンもガスジェネレータの構成は全く 同様である. 


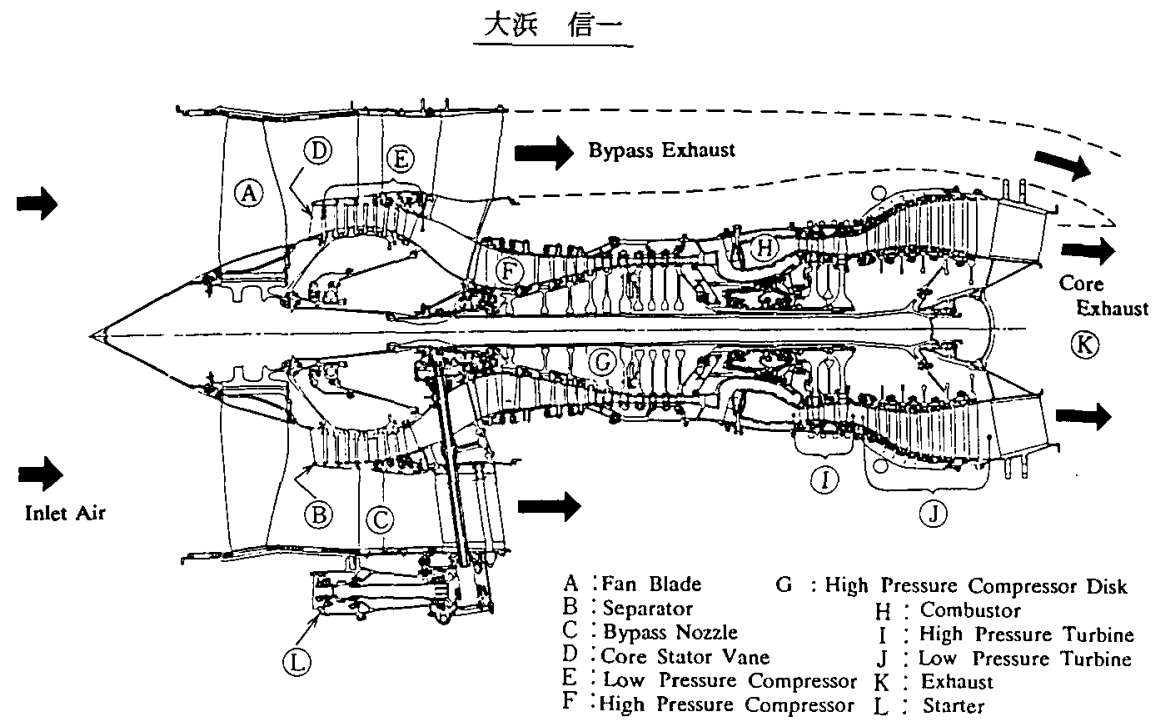

Fig. 1 IAE V2500 Aeroengine.

このガスジェネレータにおいては，圧維機では 動翼が高速で回転することによって空気が王縮さ れ，その空気温度は圧縮機の後段侧で圧縮比と共 に上昇する。また燃烧器で燃㮱した高温高压のガ ス流によってタービン動翼が回転する。したがっ てここに用いられる材料はそれぞれの部分の温度 域において，静止体では主として熱応力と王力， 回転体では熱店力と遠心力に酎える力学的特性之 耐熱性を必要とする。

ガスジェネレータの愁㤎象を间上するためには Fig. $2^{21}$ に示すように压縮機の王力比を上げ，夕 ービンに入る燃姯ガス盜度 (TET:Turbine Entry Temperature ,TIT : Turbine Inlet Temperature) を上昇させることである.

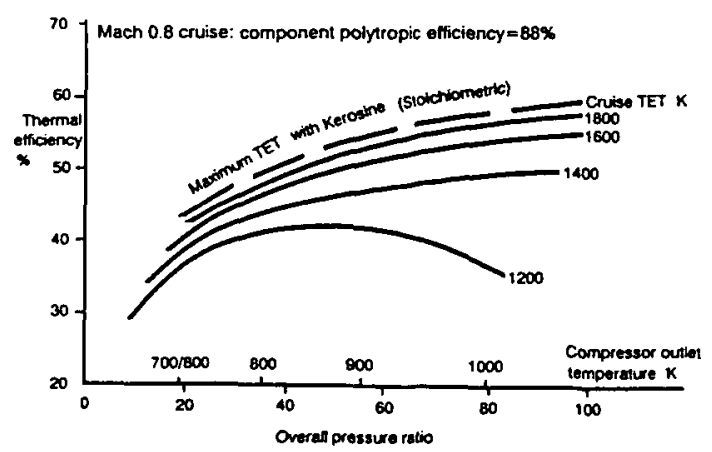

Fig. 2 Cycle Efficiency of Gas Generator.

Fig. 3 "に航空エンジンの圧力比と燃料消費率 の関係，Fig. $4^{31}$ にタービン入口温度の上昇の動 向を示す．最近のガスタービンでは，欧縮機で压
縮する空䜪の王力比は 30 を超えるので,これに 伴って压縮機の最終段の空気温度は $850 \mathrm{~K}$ 程度 に上昇する。またタービン入口温度は $1750 \mathrm{~K}$ のレベルに到達している.



Fig. 3 Total Specific Fuel Consumption

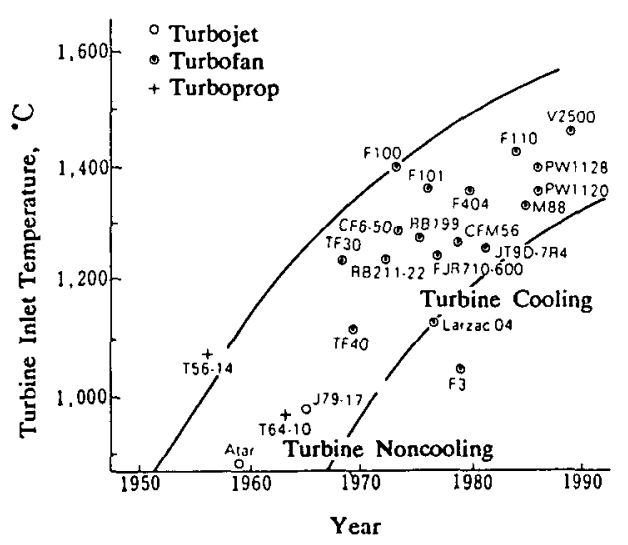

Fig. 4 Trend of Turbine Inlet Temperature. 
Fig. 5 '1に航空エンジン 1 台当りの材料の構成 割合の推移を示す.ジェットエンジンを搭載した 航空機が初飛行に成功したのは1939年であっ たが，本格的にジェットエンジンの設計・生産が 軌道に乗り始めた1950年代では材料の $90 \%$ 近くは鉄系の合金であった，前述したようにガス タービンの性能向上を目的として各要素の回転速 度と温度が上昇してきたのにしたがって，軽量で かつ比強度の高いチタン合金が用いられ，さらに $750 \mathrm{~K}$ 以上の高温の部分では $\mathrm{N}$ i 基を主体とし た耐熱超合金が多用されるに至った。今日では， チタン合金が $40 \%$ 近く、ニッケル合金が $50 \%$ を超える航空エンジンも出現するようになった。

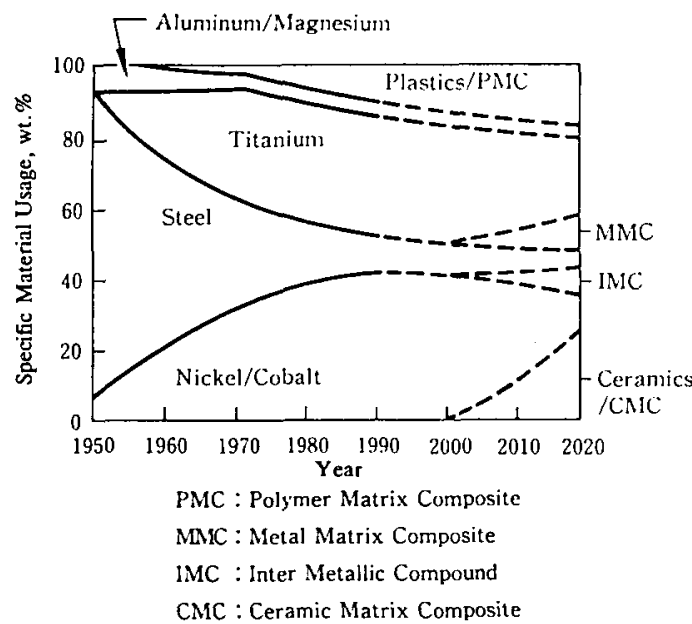

Fig. 5 Trend of Material Usage in Aeroengine

ガスタービンの性能向上あるいは推力/重量比 向上への意欲は非常に強く，これを実現するため にはFig.6 に示したように，従来の材料より 比強度の高い材料および耐用温度の高い材料，い わゆる高性能な先進材料が不可欠である。このよ うな見地から，Fig. 5 の 2000 年以降の航空工 ンジンの構成材料として，複合材料を主体とした 先進材料が予測されるに至った。

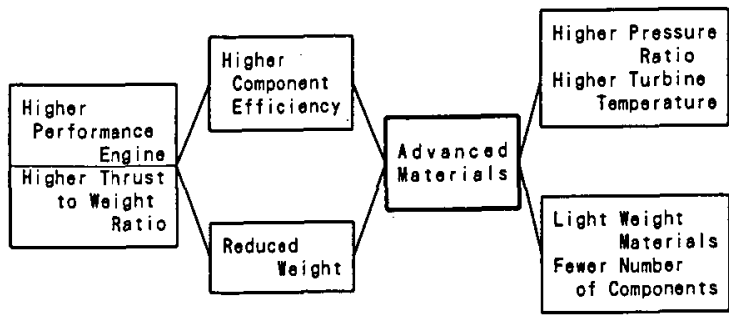

Fig. 6 Needs of Advanced Materials.

\section{3 複合材料適用ガスタービン}

近来のガスタービンに対する社会的な要請は， 低燃費化，環境適合性そして航空エンジンに対し ては小型・轻量化である。これらを実現するため には前述したようにガスジェネレータの高温・高 压化を図らなり机ばならないが，従来の金属・合 金を中心とした材料では力学的特性と耐熱性の面 で限界に近づいてきたと考えられる。

即ち，ガスジェネレータの圧縮機及びタービン の回転体の構成部品は高速回転による遠心応力に 酎えねばならないが，この遠心応力は回転速度の 2 乗之材料の密度に比例するので，回転速度と材 料の比強度との間には Fig. $7{ }^{51}$ のことき関係が 成立する．従来の金属材料では回転速度 500 m/s が限界と考えられているが， 2 倍の比强度を 持つ複合材料を適用することが可能となれば， 700 四 $/ \mathrm{s}$ の回転速度が実現することになる．

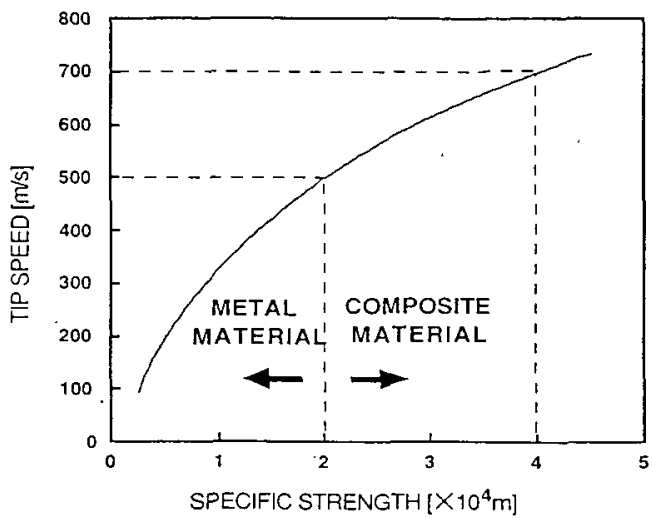

Fig. 7 Materials Capability for Tip Speed



Fig. 8 Trend of Material Temperature. 
また, $1700 \mathrm{~K}$ 前後の高温の燃狫ガスにさら される燃烧器及び夕ービンの構成部品はFig. 851 に示すように，従来の耐熱超合金の場合は材料と しての耐熱温度が $1200 \sim 1300 \mathrm{~K}$ 程度であ るので，この温度を超えないように压縮機で压縮 された空気を用いて冷却をしなければならない． このためにガスジェネレータの熱勃率として非常 に大きな損失を伴うことになる。したがって材料 の耐用温度を上けることによって冷却空気量を減 らすかおるいは無冷却とすることが，高温・高圧 化と共に熱効率向上の重要な鍵となる．Fig. 95) に燃料消費率 (T S F C : Total Specific Fuel Consumption)低隇に及ぼす無冷却の效果を示す。

これに応える材料として，七ラミックマトリック スをセラミック䄉維で出䩗化した複合材料（CM C : Ceramic Matrix Composite) が期待される.

この要請を受けて，革新的なガスジェネレータ に必要とする複合材料を主体とした先進材料の研 究プロジェクトが平成 5 年からスタートした。こ の研究を始めるに当って，各コンポーネントに先 進材料を利用することによって想定される革新的 なガスジェネレータの諸元を Table 151 のごと く設定し、これに必要な力学的特性と Table 2 に示すような各材料の耐用温度から各コンポーネ ントへの先進材料の割付けを Fig. 1051のように 行なった。

本研究プロジェクトの研究範囲はFig.11 の鎖 線で囲まれた範囲内であるが，最も特徴的な点は ガスジェネレータの各パーツの糵造設計—複合 材料設計 一 緉維酉向設計の技術を確立すると共
に，それに対応した複合材料部品の成形技術を確 立し，それをエンジン部品としての評俩試匰まで 行なう点にある。

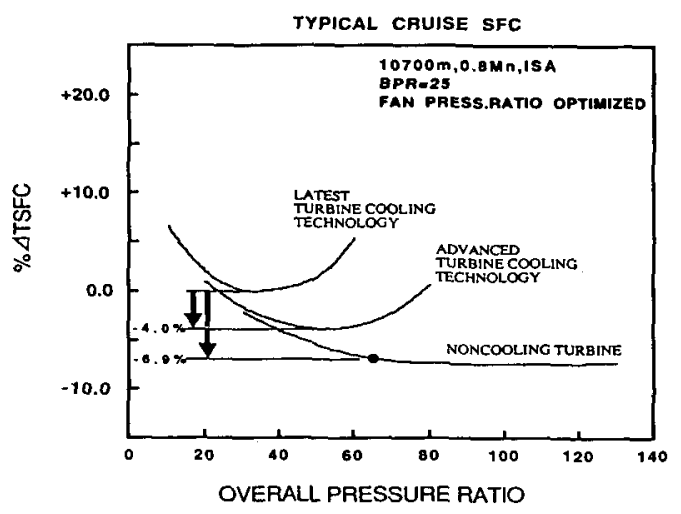

Fig. 9 Turbine Noncooling Effect on TSFC.

Table 1 Technical Targets of Each Component

\begin{tabular}{|c|l|c|}
\hline COMPONENTS & \multicolumn{3}{|c|}{ TECHNICAL TARGETS } \\
\hline \multirow{2}{*}{ COMPRESSOR } & $\begin{array}{l}\text { - Inlet Temperature } \\
\text { - Tip Speed } \\
\text { - Outlet Temperature }\end{array}$ & $\vdots 1000 \mathrm{~K} / \mathrm{s}$ \\
\hline \multirow{2}{*}{ COMBUSTOR } & $\begin{array}{l}\text { Inlet Temperature } \\
\text { - Noncooling } \\
\text { - Outlet Temperature }\end{array}$ & $\vdots 1000 \mathrm{~K}$ \\
\hline \multirow{2}{*}{ TURB I NE } & $\begin{array}{l}\text { - Inlet Temperature } \\
\text { - Tip Speed } \\
\text { - Noncooling }\end{array}$ & $\vdots 1870 \mathrm{~K}$ \\
\hline
\end{tabular}

Table 2 Temperature Capability of Materials

\begin{tabular}{|c|c|}
\hline Materials & $\begin{array}{l}\text { Approximate Temperature } \\
\text { Capability } \\
\text { (K) }\end{array}$ \\
\hline $\begin{array}{l}\text { PMC : Polymer Matrix Composite } \\
\text { (Carbon Fiber/Polyimide) }\end{array}$ & 580 \\
\hline $\begin{array}{l}\text { MMC : Metal Matrix Composite } \\
\text { (SiC Fiber / Ti Alloy) }\end{array}$ & 720 \\
\hline $\begin{array}{c}\text { I MC: Inter Metallic Compound } \\
(\mathrm{T} \text { i A I) }\end{array}$ & 1000 \\
\hline 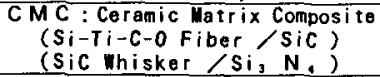 & $\begin{array}{llll}1 & 7 & 5 & 0 \\
1 & 6 & 0 & 0\end{array}$ \\
\hline
\end{tabular}

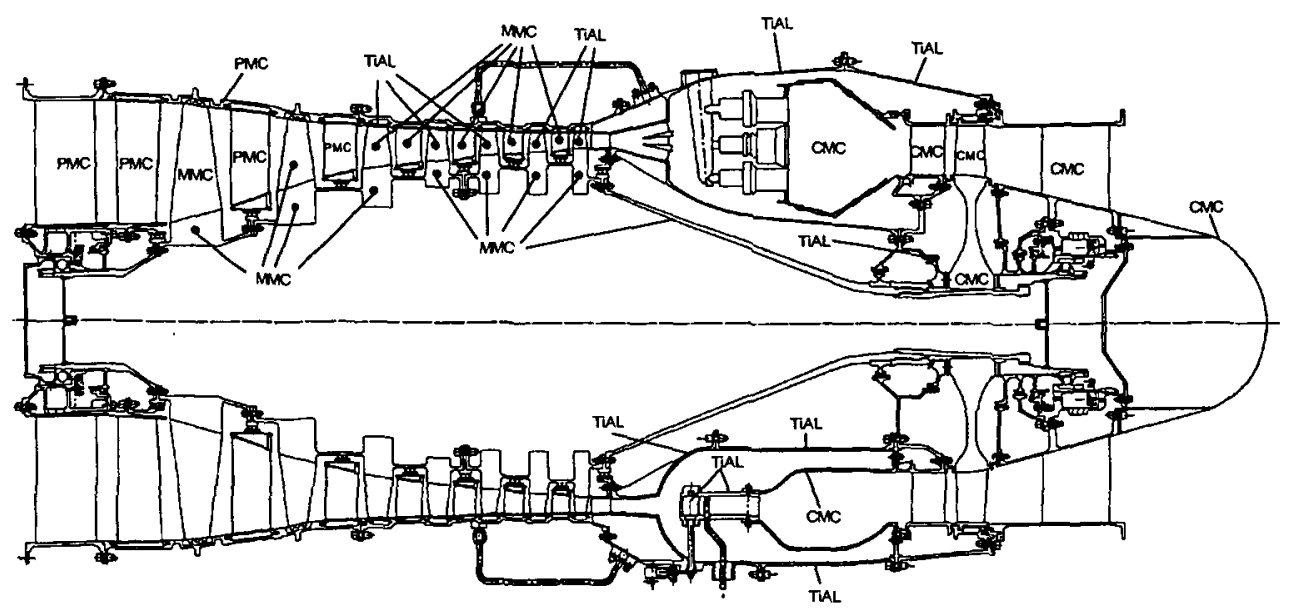

Fig. 10 Candidate Advanced Materials of Innovative Gas Generator. 


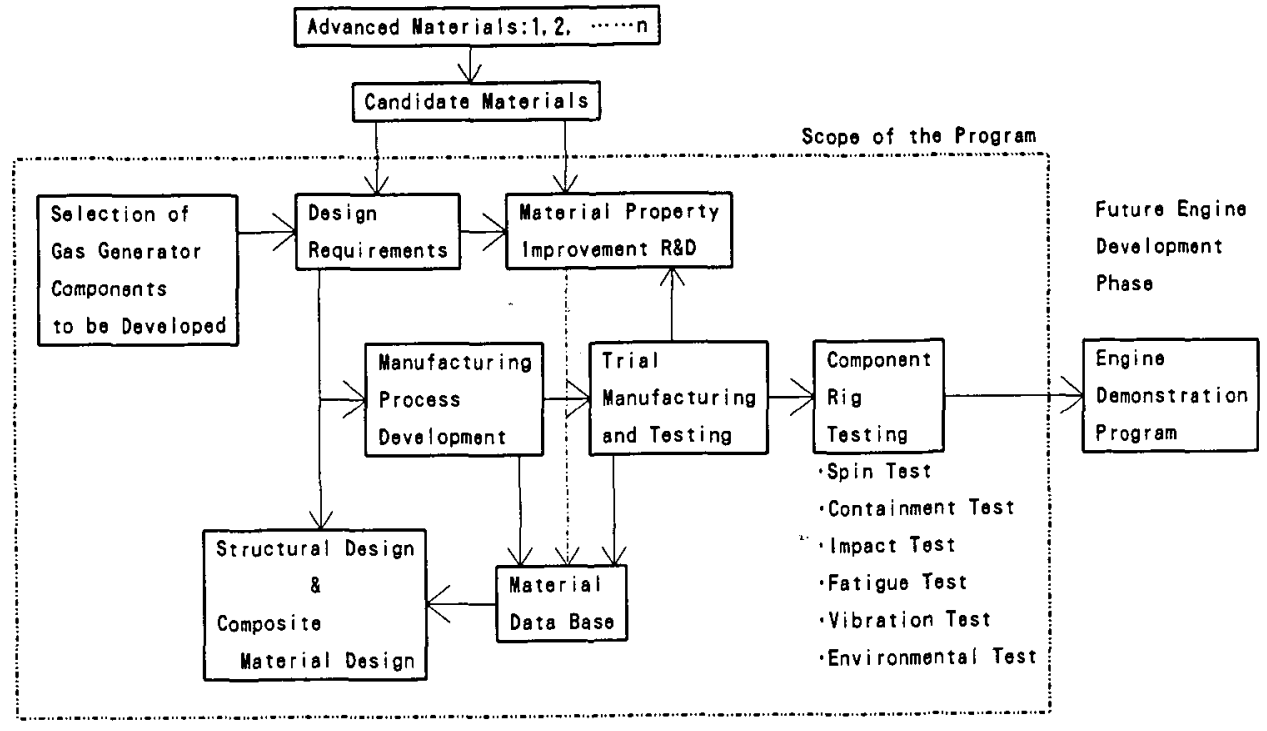

Fig. 11 Scope of R\&D Program

4 カスタービン用複合材料研究開発の現状

\section{1 耐熱樹脂複合材料}

ポリイミド樹脂をマトリックスとし，炭素䋞維 で強化した複合材料（P M C : Polymer Matrix Composite）による, 温度 $580 \mathrm{~K}$ を上限とした 代樎機のダクトと静翼の試作研究を進めている.

一般的に，Fig.12 に示すように樹脂の耐熱狌 が增す程成形が困難となるが，榯脂の選定（熱硬 化性樹脂としてPMR 15 , 熱可塑性樹脂として P I - X) と，その成形技術の改良によって目硒 を達成する計画となっている。

PMC成形の例として，Fig. 13 K 可変静翼 (V S V : Variable Stator Vane) の成形形状と Fig. 14 に熱硬化性樹脂を用いた成形プロセスを, またFig. 15 に固定静翼(Shrouded Stator Vane) の皘層構成案と Fig. 16 に热可塑性樹脂を用いた
成形プロセスを示す、いずれも実部品が受ける纫 力状態による強度解析と強度評価試験を実施して いる。これらの複合材料は密度が $1.6 \mathrm{~g} / \mathrm{cm}^{3}$ で あるからこの部分の重量軽減に大きく寄与すると 期待されている.

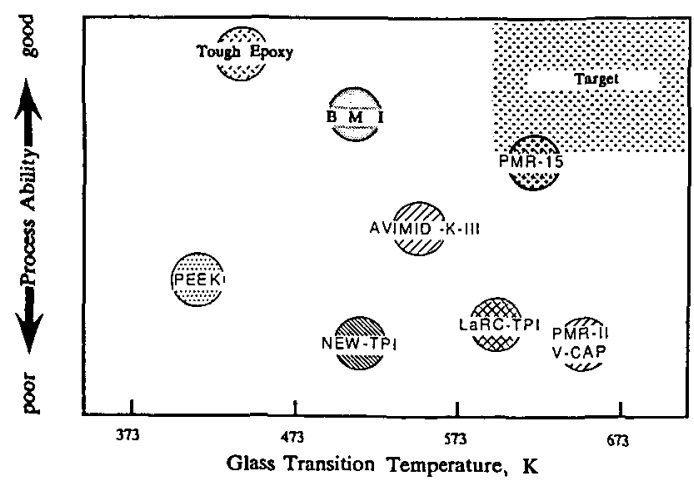

Fig. 12 Characteristic of Heat Resistant Polymer Resin
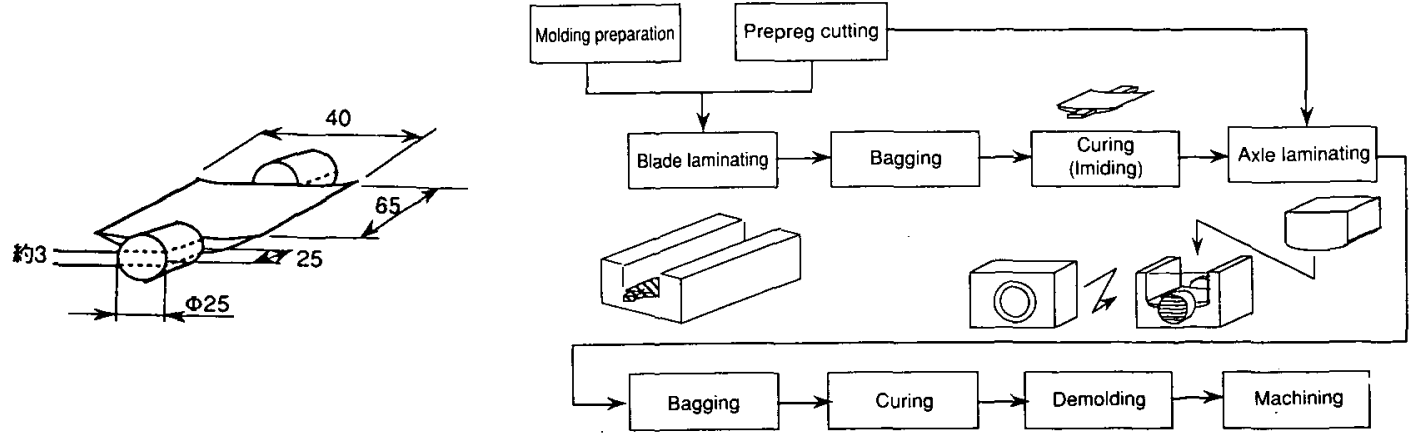

Fig. 13 Model Shape of VSV.

Fig. 14 Manufacturing Process for Variable Stator Vane. 


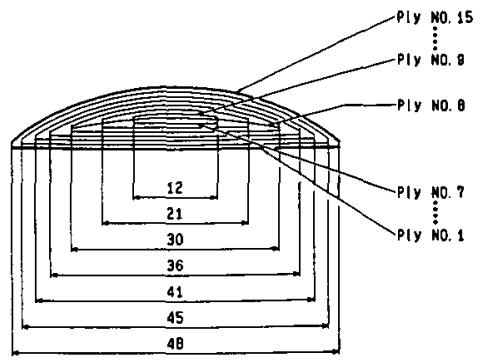

$\left[0, /-30^{\circ} / 30^{\circ} /-60^{\circ} / s^{2}\right]$

Fig. 15 Lay-up Composition of Airfoil Section of Stator Vane.

\section{2 金属基複合材料}

王樎機の前段で高速度で回転しているロータ部 品への, 金属基複合材料 (MMC：Metal Matrix Composite）の適用研究が進行している. MM C としては，前述したように高速回転に耐えるため には高比虫度の材料であることが解提であり，し かも750K程度の温度までは使うことができる ように，炭化ヶイ素（S i C) の長蟣維（連続緎 稚）で蚠化した T i 合金マトリックスの複合材料 が砂究の対象である。

S i C 䄉維としては太径のCVD織維を用い, T i 合金としては塑性加工性の良いS P - 7 00 合金及びより高温度域を対象とした T i - $6-2$ -4-2合金を選定して, ロー夕部品の構造設計, 材料特性，および成形砄究を実施している.

Fig. 17 に に P - 700 をマトリックスとし た複合材料の高温強度特性, Fig. 18 にロー夕・ ブリング（BRING:Blade and Ring）の成非プロセ スの一例を示す。



Fig. 17 High Temperature Tensile Properties of MMC

\section{3 七ラミック愎合材料}

\subsection{1 燃焼器用セラミック複合材料}

彗冷却で高温に耐えしかも軽量な㜣㜇器を開発 するために，七ラミック複合材料 (CHC:Ceramic Matrix Composite）による燃焼器ライナの砄究を 進めている，設計上のライナの最高温度は 167 OKであって, 強化維維は炭化ケイ素系 ( $\mathrm{Si}-\mathrm{Ti}-\mathrm{C}$ -0)の長織維, マトリックスは炭化ケイ素である.



Fig. 18 Shape Forming Process of MMC BRING . 




Ceramic Fiber

Preform making

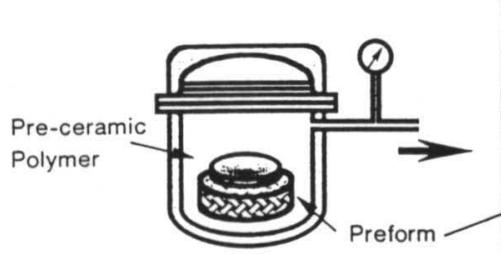

Polymer Impregnation and Pyrolysis

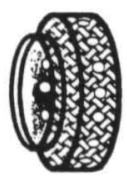

Machining

Fig. 19 Manufacturing Process of Combustor Liner.

Fig. 19 にライナの成形プロセスを示す. プリ フォームは, 応力解析によって最適の織維角度を 設定し，それにしたがってフィラメントワインデ イングを行なう。このプリフォームに前駆体ポリ マー(Pre-Ceramic Polymer)を含浸し焼成する.

Fig. 20 に成形したライナの写真を示す.

燃焼器を構成する各部品は温度的には苛酷であ るが, 応力の面では主として部品自身の温度差に よる熱応力と, 他部品との熱膨張差に起因する熱 応力であるから, 材料強度に対する要求は後述の 回転部品程には高くはない. したがって, セラミ ック複合材料としては早期に実現する可能性が高 いと考えられている.

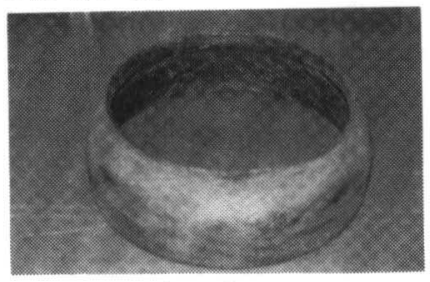

Outer liner

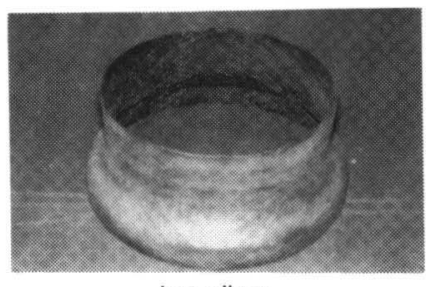

Inner liner

Fig. 20 Trial Composite Material Liner.

\section{3.2 タービン静翼用セラミック複合材料}

$$
\text { タービン静翼はタービン入口に位置するので, }
$$

静翼は作動ガスのタービン入口温度にほぼ近い温 度になる。したがって静翼は燃焼器ライナと同様 に温度的には苛酷であるが回転部品ではないので セラミック複合材料として強度よりも成形性を重 視し, 短織維強化あるいはウィスカ強化を選定し た.
S i Cウィスカ強化窒化ケイ素によるタービン 静翼の成形プロセスを Fig $21{ }^{71}$ に示す. 本プロ セスにしたがって製作した静翼は Fig $22{ }^{71}$ に示 すように, ウィスカが表面に沿って配列した形と なり静翼の強度上有利であると考えられる.

この材料は焼結助剤によってその特性がかなり変 化することが知られているが, Fig. $23^{7}$ のよう に新規の焼結助剤を用いることによって室温及び $1673 \mathrm{~K}$ の強度が各段に向上する.

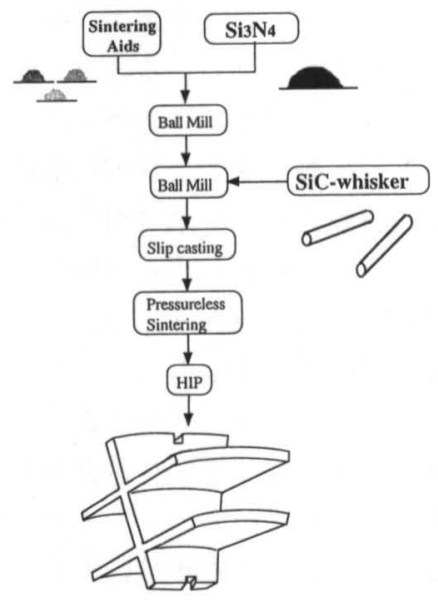

Fig. 21 Manufacturing Process of Turbine Stator Vane.

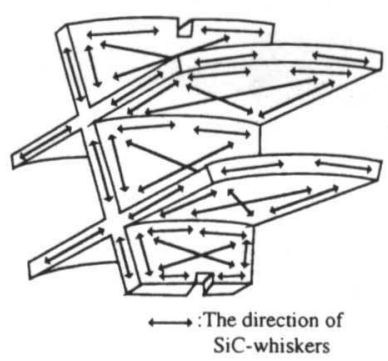

Fig. 22 Whisker Orientation in CMC Stator Vane. 

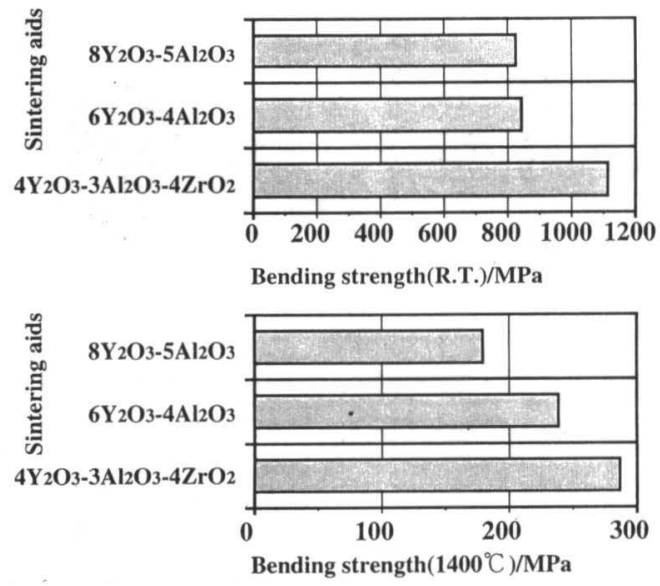

Fig. 23 Strength of SiC Whisker Reinforced CMC.

\section{3.3 タービンロータ用セラミック複合材料}

タービンロータは翼とその回転を支えるティス クで構成されるが, 翼には高温の燃焼ガスが当る のでその雰囲気温度において遠心応力に耐えるク リープ特性が必要である. またティスクは翼より 低温ではあるがその絽り返し応力に耐える低サイ クル疲労特性が必要である. 本研究では翼とディ スクが一体となったブリスク (BLISK:Blade and Disk）の開発を進めているので, 上述した苛酷で 複雑な強度要求に応えるために, 炭化ケイ素 (Si -Ti-C-0 ）長紻維を強度解析に対応した配向を持 つ 3 次元織物とし, 化学気相含浸 (CVI:Chemical Vapor Infiltration) 法と前駆体ポリマー含浸焼 成 (PIP:Polymer Impregnation and Pyrolysis) 法によって成形し評価を行なっている. Fig. 24 ${ }^{81}$ に,ブリスクの成形プロセスと Fig. $25^{8)}$ に試作 した例を示す.セラミック複合材料は Fig. $26^{81}$ に示すょうに織維配向によって材料特性が大きく 異なるのは勿論であるが, 織維とマトリックスの 界面の性状がその特性の鍵を握っているといって も過言ではない.

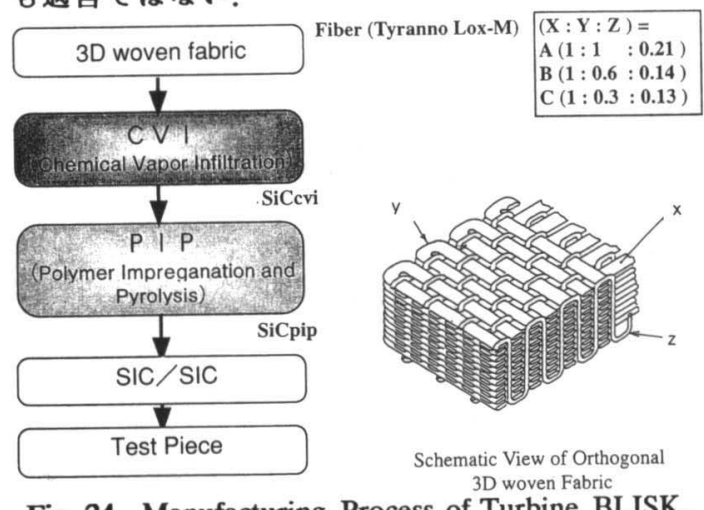

Fig. 24 Manufacturing Process of Turbine BLISK.

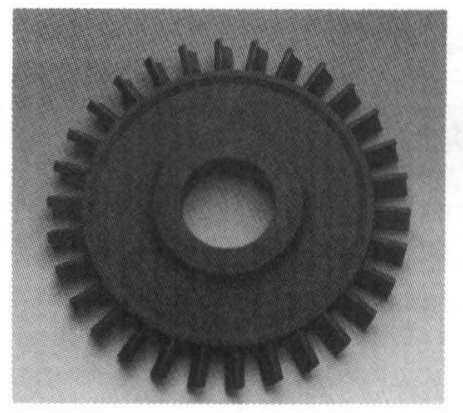

Fig. 25 Trial CMC Turbine BLISK.

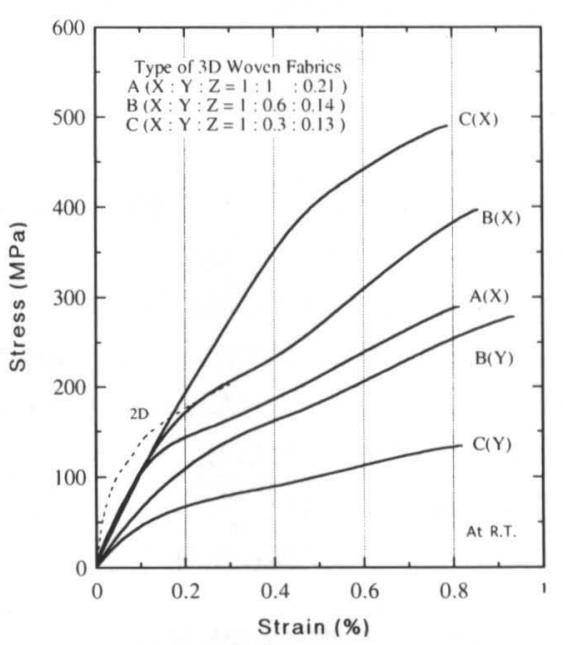

Fig. 26 Tensile Stress-Strain Curves of 3D CMC.

\section{5 蛣 言}

複合材料の研究開発が活発に行なわれている中 で, 耐熱性と高比強度を主眼とした主として長織 維強化複合材料の研究開発は, 技術的先端性が高 い分野であると考えられる。このような複合材料 をガスタービンに適用するための複合材料設計技 術, 複合材料成形技術およびその評価試殹といっ た一連の研究開発は国内外でも類を見ないもので あり, 成果が期待されると共にその成果がガス夕 ービンの性能向上に大きく貢献することを願って 止まない.

\section{文献}

1)吉中: TECHNOLIFE, オ-ム社, (1994), 14, 96 .

2)G. E. Kirk: ASME GT Congress, 89-GT-313, (1989).

3)大浜 : ガスタービン学会訫, $66,(1989), 3$.

4)大浜：航空技術，482，(1995)， 26 .

5)M. Hi romatsu : 95-YOK0HAMA-IGTC-116, 134 (1995).

6)藤原：日本複合材料学会第20回ジ䊉加。（1995）。

7)F. Sasaki : ACS, 20th Annual Conference, (1996).

8)S. Masaki, K. Moriya, T. Yamamura:HT-CMC-2(' 95). 